\title{
2 次側スイッチによる位相制御方式ハーフブリッジ共振形コンバータ
}

\author{
○八釣 成功 藤原 耕二 石原 好之 戸高 敏之 \\ 同志社大学大学院 工学研究科 電気工学専攻
}

\section{1. はじめに}

近年、高度情報化社会による情報通信機器の高性能化に 伴い、駆動するための電源装置の小型・軽量、高効率、低 ノイズ化が強く求められている。

本研究では、 $30 \mathrm{~W}$ 級の小容量 DC-DC 電源装置を対象に、 2 次側位相シフト駆動により、固定周波数での出力制御が可 能なハーフブリッジ共振形コンバータを提案し、実験によ り 2 次側位相シフト駆動を適用した提案回路の有効性につ いて検討したので報告する。

\section{2. 回路構成と䵢作原理}

Fig.1 に提案する 2 次側スイッチによる位相制御方式ハー フブリッジ共振形コンバータの回路構成を示す。従来の八 一フブリッジ共振形コンバータの 2 次側整流ダイオードと、 直列にスイッチを付加した構成になっており、1 次側スイッ チに対し、2 次側スイッチの位相を変化させることで出力を 制御する。また、絶縁高周波トランスにはプレナコアを使 用し、損失が小さくなるように設計した。

\section{3. 実験結果}

実験は、入力電圧 $140 \mathrm{~V}$ 、出力電圧 $24 \mathrm{~V}$ 、スイッチング周 波数 $500 \mathrm{kHz}$ で行った。回路定数は、共振用キャパシタンス $C_{1}=17 \mathrm{nF}$ 、トランスの巻数比 $n_{1}: n_{2}: n_{3}=14: 5: 5$ 、励磁インダク タンス $L_{\mathrm{m}}=200 \mu \mathrm{H}$ 、漏れインダクタンス $l_{1}=4.65 \mu \mathrm{H} 、 l_{2}=225 \mathrm{nH}$ である。Fig. 2 に位相差 $0.2 \mu \mathrm{s}$ とした場合の各部の電圧、電 流波形を示す。1 次側スイッチ $\mathrm{S}_{2}$ ではZVS、2 次側スイッチ $\mathrm{S}_{3}$ ではZCS が実現できることが確認できた。Fig.3に位相特 性を示す。出力電圧 $24 \mathrm{~V}$ で制御するために位相を変化させ ている。固定周波数で動作させた場合でも、出力電力が位 相差にほぼリニアに変化することから、位相制御が容易に 行えることが分かる。Fig.4 に従来のハーフブリッジ共振形 コンバータで時比率制御した場合と、提案回路で位相制御 した場合を比較した効率特性を示す。軽負荷時では、時比 率制御の場合、時比率を小さくすることによるZVS 崩壊や 振動のために効率が低下したが、位相制御の場合では、時 比率が固定なので、全範井で ZVS が実現でき、効率が改善 できる。

\section{4. まとめ}

本稿では、2 次側スイッチによる位相制御方式ハーフブリ ッジ共振形コンバータを提案し、実験結果の諸特性より 2 次側位相シフト駆動を適用した提案回路の有効性を明らか
にした。出力電力が位相差に対してほぼリニアに変化し、 出力電力 $30 \mathrm{~W}$ で効率 $90.8 \%$ が得られた。

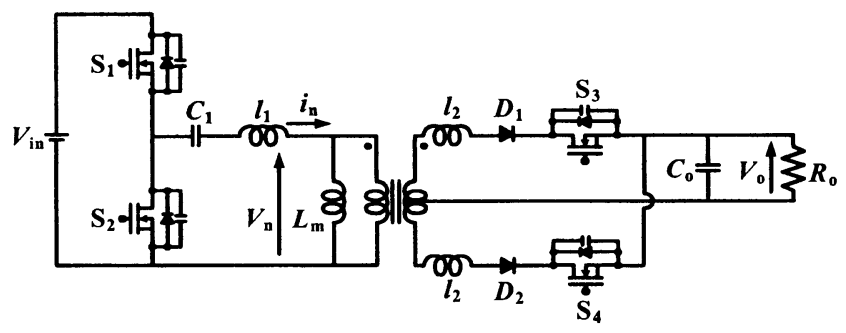

Fig. 1 提案回路

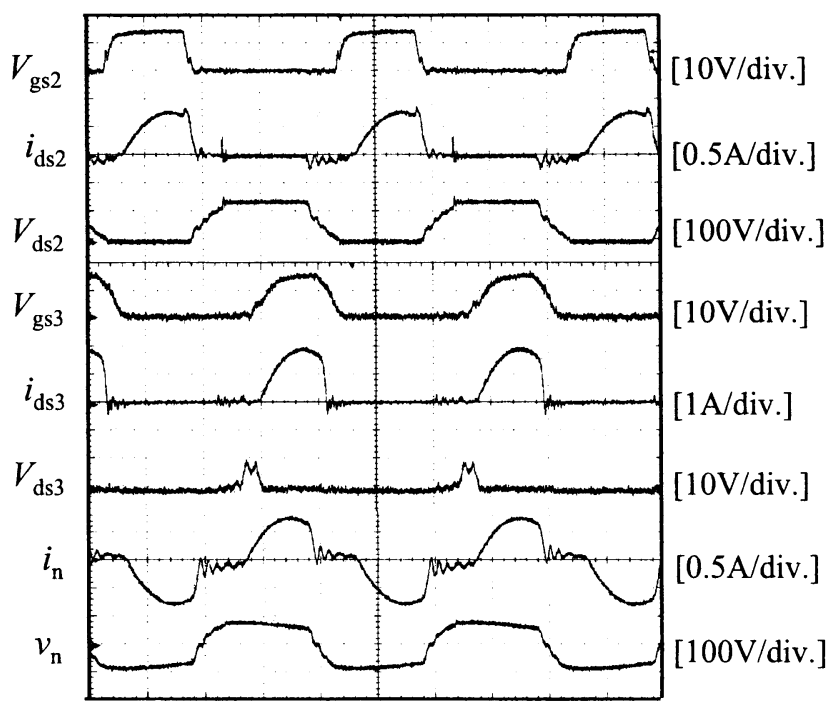

Fig. 2 動作波形 (位相差 $0.2 \mu \mathrm{s}$ 、出力 $20 \mathrm{~W}$ )

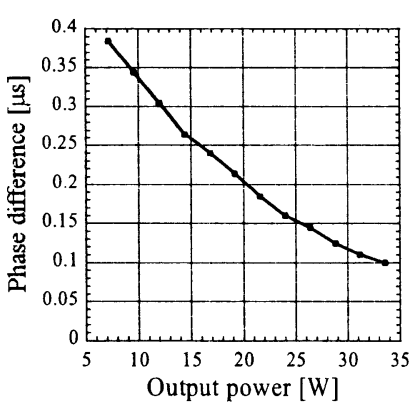

Fig. 3 位相特性 $\left(V_{\text {out }}=24 \mathrm{~V}\right)$

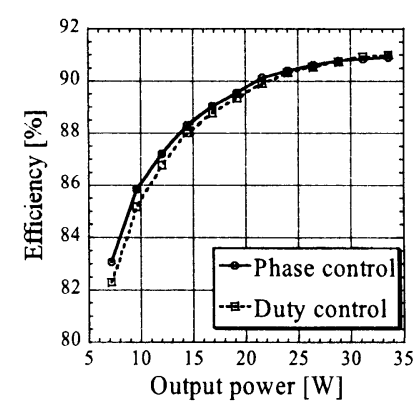

Fig. 4 効率特性 $\left(V_{\text {out }}=24 \mathrm{~V}\right)$

\section{文献}

[1] 原田、石原、戸高：「2 次側スイッチを有するゼロ電圧スイッチング PWM ハーフブリッジコンバータ」, 電子情報通信学会論文誌, Vol.J80-B-1, No.11, pp.823-829, 1997. 